\title{
ЭВАКУИРОВАННЫЕ ДЕТИ: ТРУДНОСТИ ВЫЖИВАНИЯ В ТЫЛУ
}

\section{НАТАЛИЯ БЕЛЬСКАЯ ${ }^{1, *}$}

\begin{abstract}
В статье рассматривается тема эвакуации детей во время Великой отечественной войны $u$ проблемы их выживания в тылу. Описание основывается на базе архивных документов и воспоминаний самих эвакуированных. Обсуждаются постановления советского государства, связанные с эвакуаџией детей, и трудности, с которыми дети столкнулись в тылу. Также рассматривается, как эвакуация отразилась на жизни, менталитете и взглядах этих детей $и$ подростков.
\end{abstract}

Ключевые слова: Великая Отечественная война, Советский Союз, эвакуация детей, тыл.

Один из «детей войны» начал свои воспоминания о годах Великой отечественной войны такими словами: «Прошло более 70 лет с тех пор, как началась война. Написаны тонны книг - воспоминаний, научных исследований, художественных произведений. Но эта тема продолжает занимать людей. Почти не осталось тех, кто пережил войну, будучи взрослыми. Уходят и те, кто были тогда детьми. Их воспоминания не менее важны. И не только потому, что они добавляют новые и порой яркие штрихи кобщей картине военного времени, - они помогают понять многое из того, как сложилась дальнейшая жизнь этого поколения» ${ }^{1}$.

Автору этих слов было в 1941 г. только 4 года. Ребенком он с семьей эвакуировался из Москвы в Омск и потом в Алма-Ату, где они провели самые тяжелые годы войны. Несмотря на детский возраст, в памяти автора отложились некоторые яркие эпизоды жизни в эвакуации. Были тяжелые моменты: автор, как многие эвакуированные дети, переболел желтухой, корью и дизентерией в годы войны. Были также и приятные вспоминания: автору запомнилась поездка с матерью в совхоз, где его «пустили пастись в кусты винограда» ${ }^{2}$ и он в первый и единственный раз в жизни ел виноград прямо с лозы.

Наша статья посвящена теме эвакуации советских детей в годы войны и их быту на местах перемещения. На базе архивных материалов исследование ознакомит читателей с трудностями и проблемами, с которыми советские власти столкнулись при эвакуации мирного населения, особенно детей. Более того, цель исследования - рассмотреть, как дети реагировали на эвакуацию и военную остановку и как они приспособились к быту на местах переселения.

\footnotetext{
${ }^{1}$ НАЦИОНАЛЬНЫЙ ИССЛЕДОВАТЕЛЬСКИЙ УНИВЕРСИТЕТ «ВЫСШАЯ ШКОЛА ЭКОНОМИКИ» (РОССИЯ).

*E-mail: nbelskaya@hse.ru

СТАТЬЯ ПОСТУПИЛА В РЕДАКЦИЮ В ФЕВРАЛЕ 2016 Г.
}

\footnotetext{
1 Личный архив Павла Ильина.

2 Там же.
} 
Период Великой отечественной войны отразился на биографии почти каждого советского гражданина, живущего в те годы. Эти годы связаны с воспоминаниями о трагедиях, кровопролитии и славе. Почти каждая семья прошла через жестокие испытания - гибель родных и близких на фронте и под немецкой оккупацией, разрушение домов и потеря имущества, ущерб для здоровья из-за тяжелой обстановки жизни в военные годы. Также одним из важнейших последствий войны является массовое перемещение мирного населения. Вторжение немецких сил на советскую территорию в июне 1941 г. заставило миллионы людей бежать из своих городов и деревень на восток страны. Железнодорожные пути были перегружены эшелонами с военнослужащими, которые двигались на запад, и эшелонами с эвакуированными, которые двигались на восток.

Эвакуация миллионов граждан в военные годы отразилась на жизни самих эвакуированных, а также и на народном хозяйстве регионов выезда и въезда. Эвакуация проходила в экстремальной обстановке, многие эвакуированные имели всего несколько часов, чтобы покинуть свои дома. Большинство ожидали, что они будут перемещены недалеко от дома и будут отсутствовать несколько недель, не больше месяца, поэтому люди брали с собой минимальное количество вещей. Так как большинство эвакуированных покинули свои дома летом и ранней осенью 1941 г., многие взяли с собой только летнюю одежду - это обстоятельство создало большие проблемы зимой 1941-1942 гг., когда эвакуированные не могли выходить на работу и в школу из-за отсутствия теплой одежды и обуви.

Обстоятельства переселения были тяжелые. Люди передвигались в переполненных теплушках, поезда двигались медленно, так что путь до места назначения часто длился несколько недель или даже дольше месяца. Поезда двигались вне расписания и часто останавливались. На остановках эвакуированные выбегали, чтобы добыть кипяток и купить еду. Так как расписания отсутствовали, в воспоминаниях детей ярко отражается страх, что поезд внезапно тронется и родители не успеют вернутся в эшелон. Эшелоны подвергались вражеским бомбежкам, о чем упоминается во многих мемуарах и заметках. Вот как описывает Абрам Цейтлин, которому в 1941 г. было 9 лет, свои воспоминания о поездке из украинского местечка Иллинцы в Кермине, Узбекистан: «Проехали полустанок с развороченными рельсами, на которых тлели обугленные шпалы, воронки от авиабомб и лежащие на боку паровоз и вагоны. Эта картина, впервые увиденная, потрясла мое детское воображение, и хотя впоследствии на нашем пути было немало разрушенных бомбами зданий, вагонов и паровозов, привыкнуть к зрелищам такого рода я так и не смог»³. Население из Украинской ССР, Белорусской ССР и западных регионов РСФСР было эвакуировано в районы Урала, Волги, Сибири и Средней Азии (особенно в Казахскую и Узбекскую ССР). Эвакуированные проживали на местах переселения до реэвакуации в 1944 и 1945 гг.

Тема жизни детей в эвакуации заслуживает особого внимания, так как дети составили существенную часть эвакуированного населения. Более того, жизнь детей в некоторых аспектах отличалась от жизни взрослых. В той или иной степени дети имели

\footnotetext{
3 Архив Мемориального музея холокоста в Соединённых Штатах. RG 31.053. «Memoirs of Abram Tseitlin,
} 1990». Материал прислан из Института Иудаики в Киеве. 
больше возможностей ознакомится с местным населением и с местными обычаями, так как они были освобождены от многих забот, которые волновали их родителей. В школах и дворах эвакуированные ребята знакомились с местными детьми и общались с ними ежедневно. С другой стороны, надо иметь в виду, что для детей война и эвакуация составляли ключевой период их жизни - это был момент созревания и развития, который отразился на их будущей жизни.

Таблица 1. Сведения о количестве эвакуированных детских учреждений и контингентах детей, прибывших в тыловые районы РСФСР, по оперативным данным на май-июнь 1942 г.

\begin{tabular}{|c|c|c|}
\hline Наименования областей, краев, АССР & Всего детских учреждений & Всего детей \\
\hline Алтайский край & 14 & 1968 \\
\hline Краснодарский край & 22 & 2619 \\
\hline Красноярский край & 4 & 621 \\
\hline Орджоникидзевский край & 36 & 4679 \\
\hline Архангельская обл. & 12 & 1321 \\
\hline Вологодская обл. & 24 & 1421 \\
\hline Горьковская обл. & 47 & 10371 \\
\hline Ивановская обл. & 15 & 1290 \\
\hline Кировская обл. & 222 & 21492 \\
\hline Куйбышевская обл. & 7 & 936 \\
\hline Молотовская обл. & 239 & 21540 \\
\hline Новосибирская обл. & 7 & 795 \\
\hline Омская обл. & 138 & 14925 \\
\hline Ростовская обл. & 6 & 639 \\
\hline Саратовская обл. & 55 & 8360 \\
\hline Свердловская обл. & 54 & 7938 \\
\hline Сталинградская обл. & 49 & 8171 \\
\hline Тамбовская обл. & 29 & 2320 \\
\hline Челябинская обл. & 231 & 30363 \\
\hline Чкаловская обл. & 79 & 7386 \\
\hline Ярославская обл. & 133 & 16446 \\
\hline Башкирская АССР & 33 & 3135 \\
\hline Кабардинско-Балкарская АССР & 4 & 800 \\
\hline Марийская АССР & 46 & 3012 \\
\hline Мордовская АССР & 19 & 2651 \\
\hline Татарская АССР & 99 & 10843 \\
\hline Удмуртская АССР & 14 & 1653 \\
\hline Чувашская АССР & 10 & 669 \\
\hline Всего & 1648 & 188364 \\
\hline
\end{tabular}

Источник: ГАРФ Ф.А-2306. Оп.70. Д.2760. Л.32.

Летом и осенью 1941 г. советское государство через Совет по эвакуации, созданный в первые дни после начала войны только, приняло меры, чтобы эвакуировать детей и матерей из прифронтовых районов и областей. Многие были эвакуированы вместе с родителями и с предприятиями и учреждениями, где работали родители. Но существенное число детей эвакуировано с детскими учреждениями - детдомами, детсадами и детскими интернатами. 19 августа 1941 г. Совет по эвакуации распорядился эвакуировать 10550 детей из детских учреждений города Москвы в Челябинскую и Молотовскую области, Татарскую АССР и АССР Немцев Поволжья ${ }^{4}$. Через месяц (13 сентября) было решено осуществить

${ }^{4}$ ГАРФ. Ф.6822. Оп.1. Д.541. Л.173-4. 
дополнительную эвакуацию школьников из столицы, в тыл были перемещены несколько сот школ-интернатов с 60000 учеников и сотрудников ${ }^{5}$. В начале октября, когда немецкие войска стояли под Москвой, советские власти усилили мероприятия, направленные на то, чтобы вывести молодое поколение из города. 9 октября было приказано эвакуировать 300000 женщин и детей из Москвы в Горьковскую, Молотовскую, Челябинскую и Новосибирскую области, Татарскую, Мордовскую, Чувашскую и Мари АССР и даже в Казахскую ССР.

Хотя Москва была одним из самых важных пунктов выезда, столица была, конечно, не единственным таким пунктом. В первые месяцы войны серией постановлений Совет по эвакуации распорядился эвакуировать членов семей рабочих и служащих из прифронтовых городов и регионов УССР и РСФСР ${ }^{7}$. В октябре было принято постановление, приказывающее эвакуировать 2600 детей из детских учреждений и 10000 матерей с детьми из Воронежа и Воронежской области в Казахскую ССР и в Саратовскую область ${ }^{8}$. В конце августа Молотов, Маленков, Косыгин и Жданов доложили Сталину, что они приняли решение эвакуировать 250000 женщин и детей из Ленинграда ${ }^{9}$. Дополнительная эвакуация детей из Ленинграда осуществлялась весной 1942 г., когда появился способ вывести людей из осажденного города. 27 мая 1942 г. Совет народных комиссаров СССР принял решение до 15 августа эвакуировать из Ленинграда 25000 детей-сирот ${ }^{10}$.

\section{Таблица 2. Данные по эвакуированным детским учреждениям, размещенным в Татарской АССР на 28 апреля 1942 г.}

\begin{tabular}{|c|c|c|}
\hline Учреждения & $\begin{array}{l}\text { Количество } \\
\text { учреждений }\end{array}$ & Контингент детей \\
\hline Дошкольные детские дома из Москвы & 21 & 2546 \\
\hline $\begin{array}{l}\text { Школьные и дошкольные интернаты г. } \\
\text { Москвы }\end{array}$ & 6 & 494 \\
\hline Ведомственные учреждения г. Москвы & 13 & 854 \\
\hline Интернаты г. Москвы & 11 & 1328 \\
\hline Школьные интернаты г. Ленинграда & 24 & 2706 \\
\hline $\begin{array}{l}\text { Смешанный интернат детей работников } \\
\text { Академии наук из Ленинграда }\end{array}$ & 1 & 194 \\
\hline Минский детский дом & 1 & 204 \\
\hline Детские дома из г. Углича & 2 & 165 \\
\hline Детский дом из г. Херсона & 1 & 223 \\
\hline Пионерлагерь из г. Орши, БССР & 1 & 160 \\
\hline $\begin{array}{l}\text { Зубцовский интернат (спецшкола) } \\
\text { Калининской области }\end{array}$ & 1 & 76 \\
\hline Детские дома Калининской области & & 1684 \\
\hline Детский сад Мурманской области & 1 & 62 \\
\hline Всего & 99 & 10883 \\
\hline
\end{tabular}

Источники: [Дети в условиях эвакуаиии ...2013: 157-58]; ЦГА ИПД РТ. Ф.15. Оп.5. Д.446. Л.104.

\footnotetext{
${ }^{5}$ ГАРФ. Ф.6822. Оп.1. Д.541. Л.240-1.

${ }^{6}$ ГАРФ. Ф.6822. Оп.1. Д.541. Л.54-55.

${ }^{7}$ ГАРФ. Ф.6822. Оп.1. Д.541. Л.119, 137, 142-144, 176, 178; ГАРФ. Ф.6822. Оп.1. Д.542. Л.51, 56.

${ }^{8}$ ГАРФ. Ф.6822. Оп.1. Д.542. Л.43.

${ }^{9}$ Из истории Великой отечественной войны (1990) // Известия ЦК КПСС, сентябрь 1990: 211-212.

${ }^{10}$ ГАРФ. Ф.А-2306. Оп.70. Д.2782. Л.1.
} 
По существующим данным, к концу весны 1942 г. в тыловых районах РСФСР было размещено 1648 эвакуированных детских учреждений с контингентом 188364 детей (табл. $1)^{11}$.

Эвакуированные дети были размещены и в других республиках СССР. Например, Казахская ССР приняла 104 детдома с контингентом 12859 детей (включая 385 детей, прибывших из разных детдомов индивидуально) и 16 интернатов из Москвы с 2304 детьми (табл. 2).

Все эти цифры не учитывают миллионы детей, которые прибыли в тыл со своими семьями.

Таблица 3. Сведения о количестве эвакуированных детских учреждений, прибывших в Казахскую ССР на 28 апреля 1942 г.

\begin{tabular}{lrr}
\hline Регион выезда & Количество учреждений & Контингент детей \\
\hline Московская обл. & 3 детских дома & 780 \\
Курская обл. & 22 детских дома & 2170 \\
Одесская обл. & 6 детских домов & 581 \\
Сталинская обл. & 5 детских домов & 630 \\
Сумская обл. & 1 детский дом & 21 \\
Черниговская обл. & 1 детский дом & 120 \\
Киевская обл. & 5 детских домов & 471 \\
Ворошиловоградская обл. & 3 детских дома & 863 \\
Смоленская обл. & 1 детский дом & 35 \\
Харьковская обл. & 21 детский дом & 3285 \\
Тульская обл. & 2 детских дома & 195 \\
Крымская АССР & 2 детских дома & 81 \\
Воронежская обл. & 18 детских домов & 1838 \\
Житомирская обл. & 1 детский дом & 133 \\
Могилевская обл. & 2 детских дома & 202 \\
Полтавская обл. & 2 детских дома & 181 \\
Рязанская обл. & 1 детский дом & 93 \\
Гомельская обл. & 3 детских дома & 355 \\
Ростовская обл. & 4 детских дома & 320 \\
Запорожская & 1 детский дом & 120 \\
Из разных детдомов прибыли индивидуально & & 385 \\
Интернаты г. Москвы & 16 интернатов \\
Всего & & 2304 \\
\hline
\end{tabular}

Источник: ГАРФ. Ф. 5446. Оп.43. Д.1054. Л.97.

Эвакуация миллионов детей из прифронтовых районов безусловно спасла жизнь многих, особенно еврейских, детей, для которых немецкая оккупация означала бы смертной приговор. Но прибытие тысячей детей, многих в тяжелом физическом и моральном состоянии, в тыловые районы осложнило обстановку в советском тылу. В тыловых районах был критический недостаток материальных средств для обслуживания эвакуированных. Проверки выявили множество серьезных проблем от недостатка топлива, оборудования, пищи, одежды и обуви до нехватки квалифицированных медицинских и педагогических кадров. Например, в Татарстане один Московский детдом с 200 детьми располагал «лишь только четырьмя пригодными комнатами» [Дети в условиях эвакуации...2013:112]. Описывая состояние эвакуированных детей в Татарстане, секретарь Татарского обкома

${ }^{11}$ ГАРФ. Ф.А-2306. Оп.70. Д.2760. Л.32. 
ВЛКСМ по школам Абдуллин писал: «особенно критически плохое состояние обнаружено в пионер[ском] лагере для латвийских детей в дер. Б. Менгер, Атнинского района, где 100\% вшивость среди детей. По два месяца дети не были в бане, в течение 1-1,5 месяца не менялось белье. $30 \%$ лагерников заражены чесоткой. Тяжелобольные дети помещаются в одном помещении со здоровыми и нет изолятора» [Дети в условиях эвакуации...2013:144$145]$.

Посещаемость школ среди эвакуированных детей снизилась из-за отсутствия обуви и одежды, высокой заболеваемости и плохих жилищных условий. Детям трудно было привыкнуть к новой обстановке, они страдали из-за разлуки с родителями. В письме к матери из интерната в г. Буинске, Татарской АССР, Нина Горинова писала: «мамуля, у нас белья почти нет, простыней и наволочек тоже, скучаем о вас. Мамуля, у меня плохо с сердцем. Я не могу дышать, потому что плачу. Мамуля, приезжай, а то валенок нет и ничего нет» [Дети в условиях эвакуации...2013:53]. Я привожу примеры по Татарской Автономной республике, но подобные проблемы, жалобы и недостатки были типичны и для других регионов.

Местные и центральные власти понимали, что тяжелые условия, в которых оказались дети в эвакуации и эвакуированные учреждения, могут привести к росту детской безнадзорности и беспризорности, и пытались принимать меры для улучшения бытового и материального состояния детей. Об этом свидетельствует серия решений и постановлений конца 1941 и начала 1942 гг. 23 января 1942 г. Совет народных комиссаров СССР принял постановление «Об устройстве детей, оставшихся без родителей», в котором предписал «совнаркомам союзных и автономных республик, исполнительным комитетам краевых, областных, городских и районных Советов депутатов трудящихся под личную ответственность председателей обеспечить устройство детей, оставшихся сиротами или потерявших родителей при переезде в другую местность, не допуская оставления детей безнадзорными» ${ }^{12}$. Это постановление также предусматривало образование комиссий по устройству детей при местных исполкомах.

В постановлении Совета народных комиссаров Казахской ССР от марта 1942 г. правительство Казахской ССР отметило тяжелое бытовое состояние эвакуированных детских домов и интернатов в республике. В этом документе руководители Казахской республики привели несколько примеров проблем и недостатков в эвакуированных детских учреждениях: «В Каскеленском интернате, Алмаатинской области, в детдоме No.3 гор. Джамбул, а также в ряде других детских домов дети спят по 2-3 человека на одной кровати, помещения отапливаются плохо и совершенно не освещаются... Многие детдома продолжают оставаться в антисанитарном состоянии, дети по месяиу не моются в бане, при детдомах и интернатах нет прачечных, медицинское обслуживание детей проводится от случаю к случаю, больные дети госпитализируются несвоевременно, а в ряде детдомов отсутствуют изоляторы» ${ }^{13}$.

${ }^{12}$ ГАРФ.Ф.5446. Оп.43. Д.1054. Л.59.

${ }^{13}$ ГАРФ. Ф.5446. Оп.43. Д.1054. Л.87. 
Чтобы справиться с этой ситуацией, Совнарком Казахской ССР обязал местные власти и Наркоматы республики немедленно принять нужные меры.

Документы, на которые я ссылаюсь, это только примеры множества постановлений, распоряжений, приказов и т.д., об улучшения материально-бытовых условий в эвакуированных детских учреждениях в годы войны, которые можно найти в архивах. Этими вопросами занимались в первую очередь Народные комиссариаты просвещения и их местные органы (областные отделы народного образования). Но ими интересовались также советские и партийные органы (республиканские Совнаркомы и Центральные Комитеты партии), а также и местные власти регионов, откуда дети были эвакуированы. Однако проблемы обустройства эвакуированных детей оказалось трудноразрешимыми. Нужные ресурсы (человеческие и материальные) просто отсутствовали в тылу. В военные годы большинство материальных и людских ресурсов направлялось Красной Армии, так что власти в тылу должны были действовать в обстановке дефицита ресурсов. В письме отделу школ Центрального комитета ВЛКСМ начальник Управления детских домов в РСФСР Коняхин отметил, что в годы войны в большой степени увеличилось количество и контингент детских домов во многих регионах. По данным на 1 ноября 1941 г. в Челябинской области количество детдомов увеличилось с 49 до 59, в Свердловской - с 22 до 25, в Мордовской АССР - с 4 до 22, в Башкирской АССР - с 25 до 50, в Татарской АССР - с 19 до 51. Коняхин отмечал, что «сектора указанных обл/край ОНО и НКП АССР, призванные непосредственно осуществлять руководство работой детских домов, чрезвычайно малочисленны по своему составу. По ряду указанных облОНО они состоят из 1-2 чел., которые конечно не в состоянии поднять всю сумму вопросов, поставленных перед ними в условиях военного времени» ${ }^{14}$. Очевидно, что, при всем желании, такие малочисленные кадры, действуя в условиях дефицита ресурсов, не могли кардинально улучшить обстановку в детских учреждениях и обеспечить нужды эвакуированных детей.

В этой сложной обстановке власти призывали на помощь советскую общественность, особенно комсомол и местные активы женщин-общественниц. Женщин призывали помогать детдомам и интернатам и проявлять внимание к детям, которые потеряли связь с родителями из-за войны. Власти также поощряли через прессу патронат и усыновление осиротевших детей. С почином движения в помощь эвакуированным детям выступили участницы областного совещания женского актива, состоявшегося в ноябре 1941 г. в городе Кирове, куда был эвакуирован из Москвы Народный комиссариат просвещения. На совещании было принято обращение ко всем женщинам области с призывом «окружить детские учреждения и детей, эвакуированных из прифронтовых районов, теплой сталинской заботой» ${ }^{15}$. В обращении говорилось, что «детям, временно оторванным от своей семьи, нужны ласка, любовь и теплая повседневная забота» и что местные женщины должны взять эту обязанность на себя ${ }^{16}$. Помогая эвакуированным детям, женщины вносили свой вклад в советскую победу над фашистским врагом и выполняли «свой долг перед родиной и народом» ${ }^{17}$. Женщины Кировской области

${ }^{14}$ ГАРФ. Ф.А-2306. Оп.70. Д.5512. Л.10об.

${ }^{15}$ ГАРФ. Ф.А-2306. Оп.70. Д.2675. Л.31-32.

${ }^{16}$ ГАРФ. Ф.А-2306. Оп.70. Д.2675. Л.31.

${ }^{17}$ ГАРФ. Ф.А-2306. Оп.70. Д.2675. Л.31-32. 
подготавливали помещения для приема детей, шили им белье, готовили пищу для вновь приезжающих. Общественницы должны были посещать детские учреждения, следить за благополучием детей и помогать педагогической работе этих учреждений.

Почин кировских женщин стимулировал рост женского движения в помощь эвакуированным детям в других областях и регионах тыла страны. Встречи женского актива происходили во многих городах, советские газеты активно публиковали статьи об активистках и их заслугах. Статьи с заглавиями «Забота о детях» и «Ты не сирота, малыш» описывали тяжелые испытания эвакуированных детей и то, как им помогали местные активисты $^{18} .28$ января 1942 г. в газете «Красная Татария» появилась статья об активистках Лаишевского района автономной республики и их работе с эвакуированными детьми. В обращении, принятом на совещании женского актива этого района, они писали: «Мы, женщины-колхозницы, служащие, интеллигенты Лаишевского района, решили окружить материнской заботой и любовью всех эвакуированных ребят. Мы организуем при каждом сельсовете, при каждом детском учреждении женский актив, который поможет в создании подсобного хозяйства, в подвозке топлива, в починке и пошивке теплых вещей, в стирке белья для детворы»[Дети в условиях эвакуации...2013:103-104]. В тяжелой военной обстановке общественная помощь сыграла важную роль в выживании детей в эвакуации, особенно оказавшихся в детских учреждениях и находившимся далеко от родителей и родственников. Опекая детей, женщины в тылу понимали, что помогают военнослужащим и жертвам войны. Эвакуация и движение в помощь эвакуированным детям демонстрировали сплоченность фронта и тыла.

Как же дети сами воспринимали свои годы в эвакуации? Если судить по воспоминаниям, для многих это был трудный, но интересный период жизни. Для эвакуированных, так же как и для остальных, путь их жизни кардинально изменился 22 июня 1941 г., и годы войны в каком-то смысле отразились на всей оставшейся жизни. Для многих детей начало войны. Выезд из дома, поездка в эшелоне - все это казалось интересным приключением. Они, конечно, сначала не понимали, что такое настоящая война, все это казалось интересной игрой. По приезде на места переселения дети часто были потрясены новой обстановкой и окружением. Всё было чуждо и необычно - местный климат и природа, местное население, местная культура и обычаи. Взрослые, конечно, тоже обращали на это внимание, но они были поглощены работой и озабочены бытовыми вопросами.

А вот в ярком воображении детей все это приобрело большое значение. В своих воспоминаниях один бывший эвакуированный писал о своем изумлении по прибытию в Узбекистан: «Здесь, в Кермине, все было необычно: язык, на котором местные жители общались между собой, палящее солнце, глинобитные дома и заборы, колоритный рынок, фрукты, ранее не виденные мною, тенистые платаны, ишаки почти в каждом дворе...» ${ }^{19}$. В эвакуации дети, многие из которых до войны не покидали свои места жительства, увидели много нового, познакомились с другими народами и культурами Советского Союза. В своей

18 Забота о детях // Правда, 31.01.1942; Ты не сирота, малыш // Правда, 04.02.1942.

19 Архив Мемориального музея холокоста в Соединенных Штатах. RG 31.053. «Memoirs of Abram Tseitlin, $1990 »$. 
статье «Село Бизяки - второй дом для эвакуированных» местная жительница из Татарстана Р.Мухутдинова писала, что «в татарском селе эвакуированным вначале все было и ново, и чуждо, и интересно. Они с удивлением наблюдали, как наши бабушки и дедушки во двор ходят с кумганом даже зимой, потом садятся на пол и читают намаз» [Дети в условиях эвакуации...2013:344-348]. Несмотря на свое изначальное изумление, дети быстро привыкали к новым обстоятельствам - они знакомились с местными ребятами и осваивали новый образ жизни. Многие дети вернулись домой из эвакуации с новыми навыками и даже иногда со знанием языков народов, среди которых они жили. Конечно, были и конфликты, и ссоры между эвакуированными и местными детьми. Но дети часто поддерживали друг друга. Иногда дружба и знакомство с военных лет оставались на всю жизнь ${ }^{20}$.

С другой стороны, в обстоятельствах войны и эвакуации детям и подросткам пришлось очень быстро взрослеть. Во многих семьях отсутствовали отцы, мужья и братья, и из-за этого изменились семейные взаимоотношения и обязанности. Дети активно помогали взрослым в быту - ходили за водой и топливом, стояли часами в очередях за хлебом, и даже подрабатывали, как могли. Во многих воспоминаниях эвакуированных в Среднюю Азию, они рассказывают, как ходили в поисках кизяка. Это были дети, большинство из которых приехали из городов и до войны даже не знали, что такое кизяк. В колхозах и совхозах дети часто выходили в поля на работу. В детских учреждениях детям было еще труднее, им приходилось справляться со многими задачами самим. Рассказывая про военные годы, прошедшая через эвакуацию Вера Бельская, говорила: «в день, когда началась война, кончилось мое детство» [Voices of Resilience 2010: 292]. В 1941 г. ей было 12 лет, она эвакуировалась с семьей из Киева на Кавказ, а потом в Киргизскую ССР. Мать ее была больна, и Бельская, несмотря на свой возраст, стала главой семьи, когда отца взяли в армию [Voices of Resilience 2010: 287-296]. Она занималась домашним хозяйством, училась в школе, а после школы работала в красильном цехе. Вот ее слова: «ведь кто-то должен был нести ответственность за семью - и я считаю, что те годы сделали из меня борца. Я, девчонка лет двенадцати - тринадцати, должна была приспособиться» [Voices of Resilience 2010: 294]. Бельская назвала свой рассказ «Военные годы сделали из меня борца» - так, по ее мнению, период эвакуации отразился на ее жизни, менталитете и характере.

Много лет история войны концентрировалась на истории фронта, армии, солдат, партизан, оккупации и т.д. История эвакуации стояла в стороне, считалось, что эвакуированные были далеко от военных действий, они жили в тылу, их-то спасли. Как видим, несмотря на то, что эвакуированные находились в тылу, они сталкивались со многими трудностями военного времени. Эвакуированные дети часто находились в очень тяжелой обстановке. Хотя они не были на линии фронта, они и те, кто им помогал, тоже вложили свой вклад в победу. Война и эвакуация оставили большой след в их жизни.

\footnotetext{
${ }^{20}$ См. Воспоминания Н.А. Буко, эвакуированной из Ленинграда, которая пишет о том, что она пошла в первый класс в эвакуации в Казани в 1942 г. и там познакомилась с девочкой, которая стала ее близкой подругой на всю жизнь [Дети в условиях эвакуации...2013: 355-363].
} 


\section{Список использованных сокращений:}

ГАРФ - Государственный Архив Российской Федерации

ЦГА ИПД РТ - Центральный государственный архив историко-политической документации Республики Татарстан

\section{ЛИТЕРАТУРА}

Дети в условиях эвакуации. Татарская АССР. 1941-1945 (2013) / Сост. И.И Ханипова,

Е.Г. Кривоножкина. Сб. док. и мат. Казань: Главное архивное управление при Кабинете Министров Республики Татарстан. 416 с.

Voices of Resilience (2010) / Shklarov S., ed. Calgary: Jewish Family Service Calgary. 


\section{EVACUATED CHILDREN: THE DIFFICULTIES OF SURVIVAL ON THE HOME FRONT}

\section{NATALIE BELSKY', *}

The article is devoted to the history of the evacuation of Soviet children during the Second World War and to the challenges they faced. It is based on archival sources as well as testimonies and memoirs. The article examines the policies of the Soviet authorities regarding the evacuation of children and the difficulties the evacuees encountered on the home front. It also considers how the evacuation influenced the children's life trajectories, mentalities and views.

Key words: Great Patriotic War, Soviet Union, children in evacuation, home front.

${ }^{1}$ NATIONAL RESEARCh University Higher SchoOl of Economics (Russia).

*CorResPondence: nbelskaya@hse.ru

DATE RECEIVED: FEBRUARY 2016.

\section{REFERENCES}

Deti v usloviyakh evakuatsii. Tatarskaya ASSR. 1941-1945 [Children in evacuation. Tatar ASSR. 1941-1945] (2013) / I.I Khanipova, EG Krivonozhkina, eds. Collection of documents. Kazan: Glavnoye arkhivnoye upravleniye pri Kabinete Ministrov Respubliki Tatarstan. $416 \mathrm{p}$.

Voices of Resilience (2010) / Shklarov S., ed. Calgary: Jewish Family Service Calgary. 